\title{
Machine milking parameters for Murciano-Granadina breed goats
}

\author{
N. Fernández, ${ }^{1 *}$ ๑) J. V. Martí, ${ }^{1}$ M. Rodríguez, ${ }^{1}$ C. Peris, ${ }^{1}$ ๑l and S. Balasch ${ }^{2}$ \\ ${ }^{1}$ Instituto de Ciencia y Tecnología Animal, Universitat Politècnica de València, 46022 València, Spain \\ ${ }^{2}$ Departamento de Estadística e Investigación Operativa Aplicadas y Calidad, Universitat Politècnica de València, 46022 València, Spain
}

\section{ABSTRACT}

In dairy ruminants, the combination of milking parameters must ensure good milking performance without harming udder conditions. Commonly, milking conditions for goats are established without having checked the admissible limits for optimal and fast milking. The aim of this study was to establish a limit combination of machine milking parameters that improves machine milking performance without altering milkability or udder status. To this end, we studied the effect of 2 combinations ( $42 \mathrm{kPa}, 120 \mathrm{cpm}, 60 \%$ vs. 44 $\mathrm{kPa}, 120 \mathrm{cpm}, 60 \%$ in terms of kilopascals of vacuum level, cycles per minute of pulsator rate, and percentage of pulsator ratio, respectively) on milk production and composition, milk fractioning during milking, SCC, teat tissue thickness variation after milking, and the milk emission kinetics parameters throughout 1 lactation period (6 mo). The 42 and $44 \mathrm{kPa}$ measured at the vacuum gauge level became average values of 37.5 and $39.3 \mathrm{kPa}$, respectively, measured at the teat sphincter level during milking. Milk flow significantly increased and total milking time decreased $25 \mathrm{~s}$ with the elevation of the vacuum level from 42 to $44 \mathrm{kPa}$ without any adverse effect on milk fractioning at milking. However, the use of $44 \mathrm{kPa}$ also showed an increase in tissue thickness above $5 \%$, and we observed a tendency of average conductivity of milk to increase, although without any adverse effect on SCC. It seems that $44 \mathrm{kPa}, 120 \mathrm{cpm}$, $60 \%$ is a possible limit combination of parameters to improve milking performance without altering milkability or udder conditions. We concluded that this combination can be used for milking Murciano-Granadina breed goats in conditions similar to those of this study (mid-level milking system and 1 milking/d), although further studies are necessary to verify its application in the case of 2 milkings/d.

Received February 7, 2019.

Accepted August 29, 2019.

*Corresponding author: nfernand@dca.upv.es
Key words: parameter combination, milkability, udder status, dairy goat

\section{INTRODUCTION}

There is recent evidence (Blasco et al., 2016) that mechanical milking of Murciano-Granadina goats is performed excessively slowly, with mean milk flows between 600 and $700 \mathrm{~mL} / \mathrm{min}$. This is much lower than the $939 \mathrm{~mL} / \mathrm{min}$ reported by Le Du and Benmederbel (1984) despite the need for a $35-\mathrm{kPa}$ average vacuum to open the teat sphincter in Saanen goats versus the $30.1-\mathrm{kPa}$ average vacuum (Fernández et al., 2015) for Murciano-Granadina breed goats. In an initial exploratory work (Fernández et al., 2015), we found that the problem of slow milking does not seem to reside in the milking machine materials but rather in the high sphincter strength of the animals and that the solution lay in increasing the vacuum level $(\mathrm{kPa})$ or pulsator rate (cycles per minute; cpm) or both. The values of the different parameters commonly used for the mechanical milking of Murciano-Granadina goats range between 40 and $42 \mathrm{kPa}, 90$ and $120 \mathrm{cpm}$, and 60 and $66 \%$ in terms of kilopascals of vacuum level, cmp of pulsator rate, and percentage of pulsator ratio, respectively (Díaz et al., 2012; Hamzaoui et al., 2013; Blasco et al., 2016). In a mid-level milking system, a combination of $42 \mathrm{kPa}$ and $120 \mathrm{cpm}$ reduced milking time by $22 \mathrm{~s}$ per goat compared with $40 \mathrm{kPa}$ and 90 cpm (both with a $60 \%$ pulsator ratio), although it was necessary to carry out long-term work with the new milking parameters to check the effect on milking ability and udder status of the animals (Fernández et al., 2015). Later, Domingo (2017) ratified this milking time reduction, and the combination $42 \mathrm{kPa}, 120 \mathrm{cpm}$, and $60 \%$ did not negatively affect udder condition in a longterm experiment. To test the hypothesis that a higher vacuum level could reduce milking time much more without adverse effects on milkability, teat condition, and SCC, this study aimed to investigate the long-term effect of 2 milking parameter combinations on milk yield and fractioning, milk characteristics (physical, chemical, and SCC), kinetic milk parameters, and teat 
tissue. Reducing milking time leads to lower labor costs and makes milking work less arduous.

\section{MATERIALS AND METHODS}

Housing and handling of the experimental animals followed the mandatory principles for care and use of experimental animals in Spain (BOE, 2013).

\section{Goats and General Procedures}

We used 48 multiparous $(2.8 \pm 0.4$ births; mean \pm SD) Murciano-Granadina breed goats $(46 \pm 1.8 \mathrm{~kg})$ at the experimental farm of the Universitat Politècnica de València (Spain). Mating was synchronized using intravaginal sponges $(30 \mathrm{mg}$ of fluorogestone acetate and 450 IU of pregnant mare serum gonadotropin; Chrono-Gest, CEVA Salud Animal, Barcelona, Spain), and all births took place over a 19-d period. At parturition, all goats were separated from their kids, kept together in the same pen $\left(\right.$ size $=1.5 \mathrm{~m}^{2} /$ goat; feeder $=$ $0.5 \mathrm{~m} /$ goat; 5 bowl water troughs) and, during the first month postkidding, milked under the same conditions: $42 \mathrm{kPa}$ of vacuum measured at vacuum gauge, 120 $\mathrm{cpm}$ of pulsator rate, and $60 \%$ of pulsator ratio. Later, goats were assigned at random to 2 groups $[\mathrm{n}=24 ; 42$ $\mathrm{kPa}$ of vacuum measured at vacuum gauge, $120 \mathrm{cpm}$ of pulsator rate, and $60 \%$ of pulsator ratio (referred to as the $42-\mathrm{kPa}$ group) or $44 \mathrm{kPa}$ of vacuum measured at vacuum gauge, $120 \mathrm{cpm}$ of pulsator rate, and $60 \%$ of pulsator ratio (referred to as the $44-\mathrm{kPa}$ group)] until the end of the lactation (6 mo postkidding) according to production level, sphincter strength, and SCC. Groups were separated into 2 pens under the same conditions cited above. All goats received the same total mixed feed ration twice daily (at 0900 and $1800 \mathrm{~h}$ ) and were subjected to once-a-day milking throughout lactation. The ration consisted of (1) a basal diet to meet minimum recommendations for maintenance plus $1.0 \mathrm{~L}$ of milk/d $\left(8.71 \mathrm{MJ}\right.$ of $\mathrm{NE}_{\mathrm{L}}, 99 \mathrm{~g}$ of MP, $8.7 \mathrm{~g}$ of $\mathrm{Ca}$, and $4.9 \mathrm{~g}$ of $\mathrm{P}$ ) including alfalfa hay ( $30 \%$ as $\mathrm{DM})$, barley straw (26\%), beetroot pulp (18\%), and orange pulp (26\%), and (2) a commercial concentrate for dairy goats $\left(6.78 \mathrm{MJ}\right.$ of $\mathrm{NE}_{\mathrm{L}}, 135 \mathrm{~g}$ of $\mathrm{MP}, 9 \mathrm{~g}$ of $\mathrm{Ca}$, and 4 $\mathrm{g}$ of $\mathrm{P} / \mathrm{kg}$ of $\mathrm{DM}$ ) to meet a total average milk yield of 3.1 and $2.5 \mathrm{~L}$ of milk/goat per day at different stages of the lactation curve. Rations were formulated according to Sauvant et al. (2007) and offered to the dams in an amount $10 \%$ higher than the calculated voluntary feed intake. A mid-level milking system (2 platforms, 12 ewes/platform, 6 milking units) was used. Dams were machine milked without any udder preparation using the following routine: machine milking (MM), machine stripping (MST), and postmilking teat dipping (Proac- tive Plus, DeLaval, Madrid, Spain). Machine stripping involved a vigorous udder massage just before the teat cups were removed. Milk production, composition, and SCC for the different stages of lactation were calculated based on the monthly testing. In addition, milk emission kinetics and teat thickness change after milking on the 48 goats were studied once a month throughout the trial (6 mo), whereas udder morphology was examined only during the first month after parturition.

\section{Experimental Data and Sample Collection}

Actual milk yield was recorded once a month, at 0800 $\mathrm{h}$ on Tuesdays. Separate measurements of the milk obtained by MM and MST were recorded. Immediately afterward, goats were injected once with 3 IU of oxytocin (Hormonipra; Laboratorios Hipra S. A., Valencia, Spain) into the jugular vein, and the udder was emptied by machine to obtained residual milk. Samples $(50 \mathrm{~mL})$ of actual (MM + MST) milk yield were collected and immediately analyzed for milk composition and SCC. Milk composition (fat and protein) was analyzed with an infrared analyzer (Milkoscan FT6000 Foss Electric A/S, Hillerød, Denmark), and SCC was determined with the fluoro-opto-electronic method (ISO, 2006; Fossomatic 5000, Foss Electric A/S). Milk yield was expressed as FCM at $3.5 \%$ fat milk using the equation proposed by Sauvant et al. (2007) for goats: FCM yield $=$ milk yield $\times\{1+[0.0075 \times$ fat $(\mathrm{g} / \mathrm{L})-35 / 0.4]\}$.

\section{Udder Morphology}

On d 20 postkidding, the udder characteristics (teat length, teat diameter at the base, teat diameter at the central section, implantation angle from the rear, implantation angle from the lateral, and udder height; Labussière, 1984) and teat-floor distance were measured. Teat sphincter strength (SS) was measured twice, on d 20 and 21 postkidding. Measurement of SS was performed acting on the regulator to increase the level of vacuum, from $0 \mathrm{kPa}$ and without pulsation, applied at the end of the teat cup until the appearance of the first spurt of milk (Marnet et al., 2001). Average values of SS measurements were recorded.

\section{Milk Emission Kinetics}

Milk emission kinetics was used to evaluate the effect of the 2 combinations of milking parameters on milk fractioning, milk flow, milking time, and other milk characteristics (temperature and conductivity). A milk meter (LactoCorder, Balgach, Switzerland) was used. The kinetic characteristics were taken from these records: MM milk volume, MST milk volume, milk volume 
in the first minute, MM average flow, MM maximum flow, MST average flow, MST maximum flow, latency (time elapsed from teat cup attachment to milk flow appearance in the claw), time of emission of the MM milk volume, time of occurrence of the MM maximum flow, time of emission of the MST milk volume, time of occurrence of the MST maximum flow, and total milking time (time elapsed from teat cup attachment to the end of milking).

\section{Vacuum Level Under the Teat}

The vacuum levels cited ( 42 and $44 \mathrm{kPa}$ ) for both experimental groups are measured in the vacuum gauge. However, what is important is the level of vacuum that occurs under the teat. To measure it, a VaDia device (BioControl, Rakkestad, Norway) was used once in the first month of the experimental period on goats with different milk flow. The average values obtained for each experimental group were recorded.

\section{Teat Thickness}

Teat-end edema created by the milking machine was estimated with a cutimeter (no. 33865; Hauptner, Solingen, Germany), measuring the teat thickness change immediately after milking according to Hamann et al. (1996). Teat thickness was defined as the distance $(\mathrm{mm})$ between the cutimeter jaws for a given applied pressure. The cutimeter had a new spring that exerted a force of $6.7 \mathrm{~N}\left(400 \mathrm{~mm}^{2}, 0.01675 \mathrm{~N} / \mathrm{mm}^{2}\right)$. Measurements of each teat were taken before and after milking as the difference between the readings taken (postmilking reading - premilking reading) and expressed as a percentage of the value measured before milking. Measurements were taken in duplicate; after the first application, the cutimeter was opened and the thickness was gauged again without changing the device's position (Isaksson and Lind, 1992).
Table 1. Mammary morphology (means \pm SD) of the MurcianoGranadina goat breed used in 2 combinations of milking parameters

\begin{tabular}{lcc}
\hline & \multicolumn{2}{c}{ Milking parameters ${ }^{1}$} \\
\cline { 2 - 3 } Trait & $42,120,60$ & $44,120,60$ \\
\hline Teat (mm unless noted) & $62.9 \pm 4$ & $63.1 \pm 4$ \\
Length & $54.5 \pm 4$ & $53.8 \pm 4$ \\
Diameter at base & $37.9 \pm 3$ & $37.5 \pm 3$ \\
Diameter at midpoint & $45.5 \pm 4$ & $45.9 \pm 5$ \\
Angle from behind & $44.5 \pm 3$ & $45.6 \pm 4$ \\
Angle from the lateral & $29.9 \pm 1$ & $30.1 \pm 1$ \\
Sphincter strength (kPa) & & \\
Udder (mm) & $185 \pm 8$ & $183 \pm 7$ \\
Distance from base to floor & $280 \pm 2$ & $283 \pm 3$ \\
Height &
\end{tabular}

${ }^{1}$ Parameters are given in terms of kilopascals of vacuum level, cycles per minute of pulsator rate, and percentage of pulsator ratio, respectively.

\section{Statistical Analysis}

Milk yield and fractioning, milk composition and SCC, variables from kinetic milk emission (milk yield and fractioning, flows and times, milk conductivity and temperature), and percentage of teat-end edema were analyzed using the MIXED procedure of SAS (SAS Institute, 2011), a repeated-measures model that included the fixed effects of lactation period $(6 \mathrm{mo})$ and experimental group ( $42 \mathrm{kPa}$ and $44 \mathrm{kPa}$ ), the random effect of animal nested in the experimental group, the interaction between experimental groups and lactation stage, and residual error. The SCC $\log _{10}$ was used to normalize SCC distribution (Ali and Shook, 1980). Separation of means, if appropriate, for the determination of a significant $(P<0.05)$ main effect was performed using pairwise contrasts (PDIFF option of SAS). When interaction was nonsignificant, the corresponding interaction was pooled with the error. The relationship between variables was carried out following the CORR procedure of SAS.

Table 2. Least squares means of milk yield and milk parturition for 2 combinations of milking parameters with the Murciano-Granadina goat breed

\begin{tabular}{|c|c|c|c|c|}
\hline \multirow[b]{2}{*}{ Trait } & \multicolumn{2}{|c|}{ Milking parameters ${ }^{1}$} & \multirow[b]{2}{*}{ SEM } & \multirow[b]{2}{*}{$P$-value } \\
\hline & $42,120,60$ & $44,120,60$ & & \\
\hline Milk yield $(\mathrm{mL})$ & 2,297 & 2,403 & 74 & 0.52 \\
\hline Machine milk (mL) & 2,103 & 2,189 & 70 & 0.63 \\
\hline Machine stripping milk (mL) & 188 & 200 & 18 & 0.49 \\
\hline Residual milk (mL) & 247 & 314 & 46 & 0.65 \\
\hline Machine milk (\%) & 91.4 & 91.7 & 0.7 & 0.75 \\
\hline Machine stripping milk (\%) & 8.9 & 9.0 & 0.8 & 0.77 \\
\hline Residual milk (\%) & 11.3 & 13.1 & 2 & 0.52 \\
\hline
\end{tabular}

${ }^{1}$ Parameters are given in terms of kilopascals of vacuum level, cycles per minute of pulsator rate, and percentage of pulsator ratio, respectively. 
Table 3. Least squares means of the composition and SCC in milk for 2 combinations of milking parameters with the Murciano-Granadina goat breed

\begin{tabular}{|c|c|c|c|c|}
\hline \multirow[b]{2}{*}{ Trait } & \multicolumn{2}{|c|}{ Milking parameters ${ }^{1}$} & \multirow[b]{2}{*}{ SEM } & \multirow[b]{2}{*}{$P$-value } \\
\hline & $42,120,60$ & $44,120,60$ & & \\
\hline Fat (\%) & $5.0 \pm 1.0$ & $5.1 \pm 1.0$ & 1.0 & 0.72 \\
\hline Protein (\%) & $3.5 \pm 0.6$ & $3.6 \pm 0.6$ & 0.6 & 0.63 \\
\hline $\log _{10} \mathrm{SCC}$ & $5.7 \pm 0.1$ & $5.7 \pm 0.1$ & 0.1 & 0.61 \\
\hline
\end{tabular}

${ }^{1}$ Parameters are given in terms of kilopascals of vacuum level, cycles per minute of pulsator rate, and percentage of pulsator ratio, respectively.

\section{RESULTS}

The udder characteristics are presented in Table 1. The sample of Murciano-Granadina goats used had teats with an average length of $63 \mathrm{~mm}$, a diameter of $54.2 \mathrm{~mm}$ at the base and $37.7 \mathrm{~mm}$ in the middle, and moderate sloping $\left(45.7^{\circ}\right.$ from behind and $45.1^{\circ}$ from the side) and an udder with an average height of $281.5 \mathrm{~mm}$ and a distance from the floor of $184 \mathrm{~mm}$.

The 42 and $44 \mathrm{kPa}$ measured at the vacuum gauge level became average values of 37.5 and $39.3 \mathrm{kPa}$, respectively, measured under the teat and with milk flow. Milking parameters did not affect milk production and fractionation at milking (Table 2) or the composition, physical characteristics, and SCC of milk (Table 3), whereas the opposite occurred for lactation period. The interaction of experimental group and lactation status was not significant in any case except average milk conductivity $(P=0.04)$. However, we observed that the milking parameters of the $44-\mathrm{kPa}$ group increased (Table 4) the difference in teat thickness before and after milking compared with $42-\mathrm{kPa}$ group. Likewise, there were statistically significant differences between the 42- and 44-kPa groups for latency, maximum flow for the machine milk, total milking time, and average milk temperature (Figure 1), whereas average milk con- ductivity was not significant (Table 5; Figure 1). None of the variables of production, composition, SCC, teat thickness variations before and after milking, or milk emission kinetics were significantly correlated with teat SS except those presented in Table 6 .

\section{DISCUSSION}

According to Such (1990), udder morphology, milk fractionation during milking, residual milk, and kinetic milk emission are some of the useful parameters to evaluate milkability. In our case, the mean value of the teat diameter at its midpoint $(37.7 \mathrm{~mm})$ places our herd in the immediately preceding score (36.6-41.5 $\mathrm{mm}$ ) in relation to teats considered to be extremely wide $(41.6-46.5 \mathrm{~mm})$ in the morphological evaluation of Murciano-Granadina goats (Ruiz, 2008). The other parameters measured are considered as means in the aforementioned morphological evaluation. In the same breed, Peris et al. (1997) obtained mean values of 28.5 $\mathrm{mm}$ for teat length $(63.0 \mathrm{~mm}$ in this experiment) and $26.8^{\circ}$ for mean angle of the teats seen from behind $\left(45.7^{\circ}\right.$ in this experiment), whereas Arrebola et al. (2006) observed a mean diameter of the teat in its middle part of $16 \mathrm{~mm}$. This means that the goats used in our experiment have a large teat size compared with those used by other authors for the same breed but are within the values considered normal for the Murciano-Granadina breed according to Ruiz (2008).

The fact that lactation status was statistically significant over most of the studied variables of production and composition seems logical given that milk production decreases and the composition of milk increases as lactation progresses, both in sheep (Requena et al., 2010) and in goats (Delgado-Pertíñez et al., 2009). In this experiment, the increase of the vacuum level from 42 to $44 \mathrm{kPa}$ did not have a negative effect on milk fractionation during milking. Values of 91 and $9 \%$ for

Table 4. Least squares means of the thickness of the teat tissues before and after milking for 2 combinations of milking parameters with the Murciano-Granadina goat breed

\begin{tabular}{|c|c|c|c|c|}
\hline \multirow[b]{2}{*}{ Trait } & \multicolumn{2}{|c|}{ Milking parameters ${ }^{1}$} & \multirow[b]{2}{*}{ SEM } & \multirow[b]{2}{*}{$P$-value } \\
\hline & $42,120,60$ & $44,120,60$ & & \\
\hline \multicolumn{5}{|c|}{ Thickness before milking (mm) } \\
\hline Right teat & 4.4 & 4.3 & 0.09 & 0.42 \\
\hline Left teat & 4.4 & 4.4 & 0.10 & 0.61 \\
\hline \multicolumn{5}{|c|}{ Thickness after milking (mm) } \\
\hline Right teat & 4.5 & 4.5 & 0.11 & 0.63 \\
\hline Left teat & 4.5 & 4.6 & 0.10 & 0.62 \\
\hline \multicolumn{5}{|c|}{ Thickness variation (\%) } \\
\hline Right teat & 3.4 & 6.0 & 0.86 & 0.05 \\
\hline Left teat & 4.1 & 7.3 & 1.06 & 0.04 \\
\hline
\end{tabular}

${ }^{1}$ Parameters are given in terms of kilopascals of vacuum level, cycles per minute of pulsator rate, and percentage of pulsator ratio, respectively. 


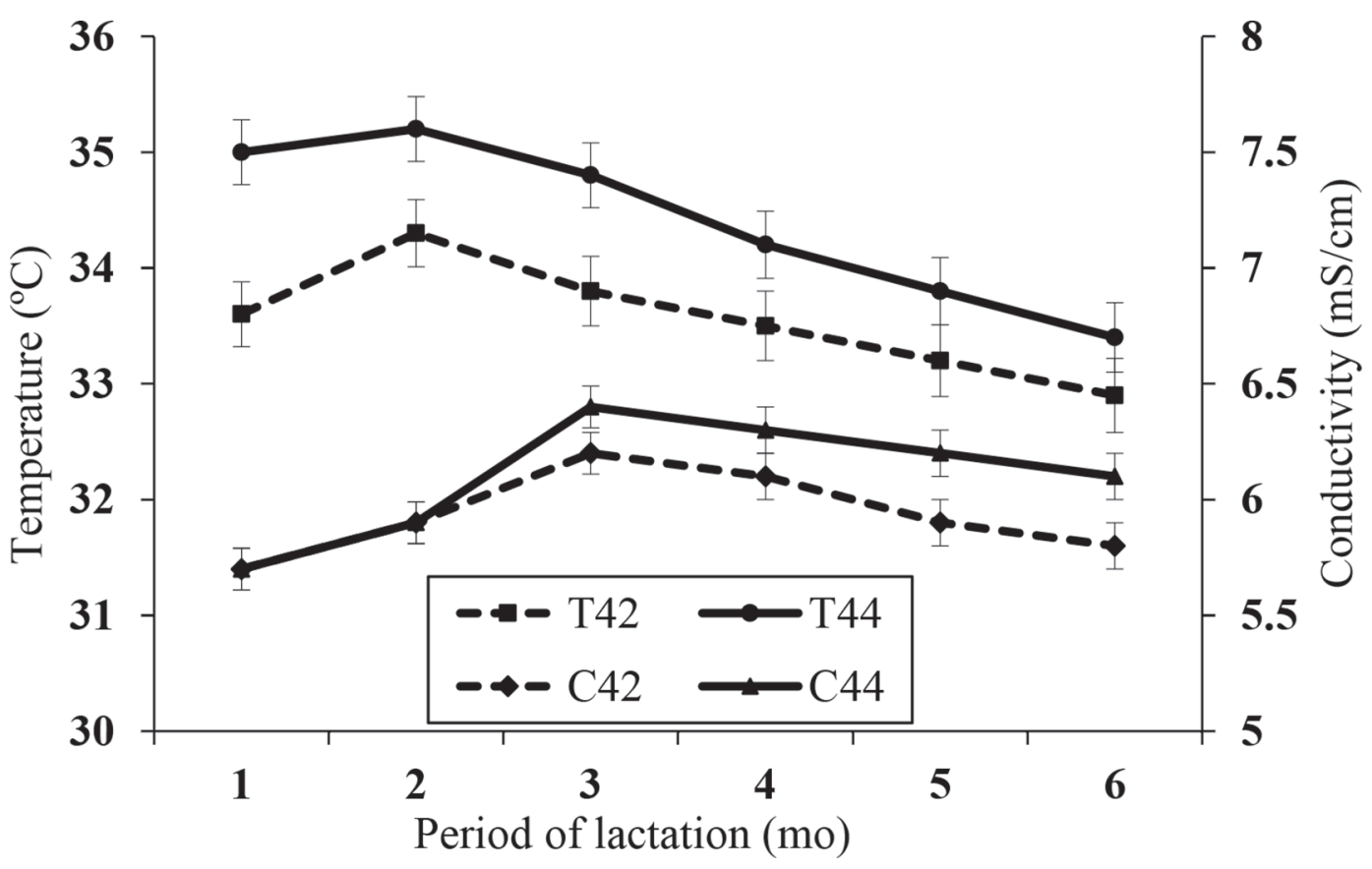

Figure 1. Least squares means $( \pm \mathrm{SEM})$ of milk temperature and conductivity for 2 combinations of machine milking parameters $(42 \mathrm{kPa}$, $120 \mathrm{cpm}$, and $60 \%$ vs. $44 \mathrm{kPa}, 120 \mathrm{cpm}$, and $60 \%$ in terms of kilopascals of vacuum level, cycles per minute (cpm) of pulsator rate, and percentage of pulsator ratio, respectively) with the Murciano-Granadina goat breed. Month 1 corresponds to the pre-experimental period. T42 = average temperature for the $42-\mathrm{kPa}$ group; T44 = average temperature for the $44-\mathrm{kPa}$ group; $\mathrm{C} 42=$ average conductivity for the $42-\mathrm{kPa}$ group; $\mathrm{C} 44=$ average conductivity for the $44-\mathrm{kPa}$ group.

MM and MST, respectively, appear to indicate a good aptitude and milking conditions; they are better than those of Peris et al. (1997) in the same breed (83 and $17 \%$ ) and those of Caja et al. (1999) in the Tenerife goat breed ( 80 and $20 \%$ ). In addition, no statistically significant differences were found for residual milk between combinations of milking parameters.

We observed that increasing the vacuum level to 44 $\mathrm{kPa}$ increased milk flow and reduced total milking time by $25 \mathrm{~s}$, achieving the objective of the work. Teat SS was negatively correlated with milk flow and positively correlated with milking time, which confirms the importance of the former trait in milking speed.

Milk temperature and conductivity are 2 parameters commonly used to evaluate the presence of mastitis in cows and goats (Gil, 1988; Mein et al., 2004; Norberg and Korsgaard, 2004; Díaz et al., 2011, 2012). Average milk temperature of the goats in the $44-\mathrm{kPa}$ group was not important in this case because this difference existed at the beginning of the experiment (month 1; Figure 1). Therefore, the interaction between lactation period and experimental group is not significant. Díaz

Table 5. Least squares means of the emission kinetic variables for 2 combinations of milking parameters with the Murciano-Granadina goat breed

\begin{tabular}{|c|c|c|c|c|}
\hline \multirow[b]{2}{*}{ Trait } & \multicolumn{2}{|c|}{ Milking parameters ${ }^{1}$} & \multirow[b]{2}{*}{ SEM } & \multirow[b]{2}{*}{$P$-value } \\
\hline & $42,120,60$ & $44,120,60$ & & \\
\hline Latency $^{2}$ (min) & 0.35 & 0.28 & 0.02 & 0.03 \\
\hline Machine milking maximum flow $(\mathrm{mL})$ & 660 & 780 & 40 & 0.03 \\
\hline Total milking time (min) & 4.07 & 3.65 & 0.13 & 0.04 \\
\hline Average milk conductivity $(\mathrm{mS} / \mathrm{cm})$ & 5.80 & 5.90 & 0.07 & 0.22 \\
\hline Average milk temperature $\left({ }^{\circ} \mathrm{C}\right)$ & 33.60 & 34.40 & 0.23 & 0.03 \\
\hline
\end{tabular}

${ }^{1}$ Parameters are given in terms of kilopascals of vacuum level, cycles per minute of pulsator rate, and percentage of pulsator ratio, respectively.

${ }^{2}$ Time elapsed between teat cup attachment and the milk flow appearance in the claw. 
Table 6. Correlation and $P$-value of the sphincter strength with some variables of the milk emission kinetics with the Murciano-Granadina goat breed

\begin{tabular}{lrc}
\hline Item & Correlation & $P$-value \\
\hline Milk volume in min 1 & -0.516 & $<0.009$ \\
Machine milking average flow & -0.535 & $<0.007$ \\
Machine milking maximum flow & -0.521 & $<0.009$ \\
Time for occurrence of machine milking maximum flow & 0.618 & $<0.001$ \\
Time of emission of machine milking milk volume & 0.600 & $<0.002$ \\
Total milking time & 0.522 & $<0.009$ \\
\hline
\end{tabular}

et al. (2011, 2012) concluded that the use of a system based on daily readings of electrical conductivity could be useful in IMI detection in Murciano-Granadina goats. In our experiment, increasing the vacuum from 42 to $44 \mathrm{kPa}$ in the $44-\mathrm{kPa}$ group did not affect average milk conductivity compared with the $42-\mathrm{kPa}$ group, although a tendency for it to increase was observed in the 44-kPa group as lactation progressed (Figure 1).

Díaz et al. (2013) demonstrated a high correlation between ultrasound and cutimeter methods for measuring teat-end edema after milking. In our experiment, the combination of milking parameters with a higher vacuum level $(44 \mathrm{kPa})$ resulted in greater edema of the teat end after milking $(>5 \%)$, although this did not lead to a higher SCC in milk. In the same breed of goats used in this experiment, Díaz et al. (2013) obtained a mean increase of $4.6 \%$ for the teat edematization after the milking, with the combination of milking parameters $40 \mathrm{kPa}, 90 \mathrm{cpm}$, and $60 \%$, which was slightly higher than that obtained in this work for $42 \mathrm{kPa}(3.4-4.1 \%)$. Zecconi et al. (1992) indicated that sudden changes in teat thickness after milking (either $>5 \%$ or $<5 \%$ indicating excessive edema or compressive load of the liner, respectively) led to risk situations for the establishment of an IMI in cattle. Also in cattle, Neijenhuis et al. (2001) observed that the teat does not recover its initial thickness until $6 \mathrm{~h}$ after the end of milking, and they affirmed that when the level of edematization is high, some substances of high molecular weight (e.g., albumin) can exude from the capillaries, requiring more time for their elimination. Alejandro et al. (2014), working with Murciano-Granadina breed goats, concluded that at least $10 \mathrm{~h}$ is required for teat walls and canal to return to their physiological conditions before milk removal. These findings seem to indicate that, given that in our work the milking interval was 24 $\mathrm{h}$, the teat tissues had sufficient time to regenerate and return to a normal situation before the next milking. Therefore, the results of this work could be valid for herds with 1 daily milking but not necessarily 2 daily milkings due to the possibility that regeneration might not take place completely at the beginning of one of the daily milkings with a milking interval of $12 \mathrm{~h}$ (or even shorter, if the intervals between the morning and afternoon were different). Therefore, it seems that 44 $\mathrm{kPa}, 120 \mathrm{cpm}$, and $60 \%$ is a limit combination parameter that could improve milking performance without altering milkability or udder conditions.

\section{CONCLUSIONS}

For virtually all milkability parameters (milk production and milk fractionation), milk composition, and SCC, increasing vacuum level from $42 \mathrm{kPa}$ to 44 $\mathrm{kPa}$, with $120 \mathrm{cpm}$ of pulsation rate and $60 \%$ of pulsation ratio, did not cause any statistically significant modification but reduced total milking time by $25 \mathrm{~s}$. This positive contribution to milking speed without adverse effects on SCC leads us to recommend use of the combination of parameters $44 \mathrm{kPa}, 120 \mathrm{cpm}$, and $60 \%$ for Murciano-Granadina breed goats for a midlevel milking system and 1 milking/d. However, further studies are needed to clarify the application of these parameters in the case of 2 milkings/d.

\section{REFERENCES}

Alejandro, M., A. Roca, G. Romero, and J. R. Díaz. 2014. Effects of milk removal on teat tissue and recovery in Murciano-Granadina goats. J. Dairy Sci. 97:8. (Abstr.) https://doi.org/10.3168/jds .2014-7934.

Ali, A., and G. E. Shook. 1980. An optimum transformation for somatic cell concentration in milk. J. Dairy Sci. 63:487-490.

Arrebola, F. A., B. J. González, M. Beltrán, M. Gil, M. Sánchez, and A. M. Dueñas. 2006. Caracterización zoométrica mediante calificación morfolineal del ganado caprino lechero de raza MurcianoGranadina en el Valle de los Pedroches. Pages 198-201 in Proc. XXXI Jornadas Científicas de la Sociedad Española de Ovinotecnia y Caprinotecnia, Córdoba, Spain. SEOC, Córdoba, Spain.

Blasco, E., E. A. Gómez, C. Vicente, G. Vidal, and C. Peris. 2016. Factors affecting milking speed in Murciano-Granadina breed goats. J. Dairy Sci. 99:10102-10108. https://doi.org/10.3168/jds.2016 -10869 .

BOE (Boletín Oficial del Estado). 2013. Real Decreto 53/2013, de 1 de febrero, por el que se establecen las normas básicas aplicables para la protección de los animales utilizados en experimentación y otros fines científicos, incluyendo la docencia.

Caja, G., J. Capote, J. L. López, S. Peris, X. Such, and A. Argüello. 1999. Milk partitioning and milk flow rate of Canarian dairy goats under once daily or twice daily milking frequencies. Pages $274-280$ in Proc. 6th International Symposium on Milking of the Small Ru- 
minants, Athens, Greece. EAAP Publication, Wageningen Pers., the Netherlands.

Delgado-Pertínez, M., J. L. Guzmán-Guerrero, Y. Mena, J. M. Castel, P. González-Redondo, and F. P. Caravaca. 2009. Influence of kid rearing system on milk yield, kid growth and cost of Florida goats. Small Rumin. Res. 81:105-111.

Díaz, J. R., M. Alejandro, C. Peris, and N. Fernández. 2013. Use of ultrasound scanning to estimate wall thickness in MurcianoGranadina goats. Livest. Sci. 155:114-122. https://doi.org/10 $.1016 /$ j.livsci.2013.04.007.

Díaz, J. R., G. Romero, R. Muelas, M. Alejandro, and C. Peris. 2012. Effect of intramammary infection on milk electrical conductivity in Murciano-Granadina goats. J. Dairy Sci. 95:718-726. https:// doi.org/10.3168/jds.2011-4698.

Díaz, J. R., G. Romero, R. Muelas, E. Sendra, J. C. F. Pantoja, and C. Paredes. 2011. Analysis of the influence of variation factors on electrical conductivity of milk Murciano-Granadina goats. J. Dairy Sci. 94:3885-3894. https://doi.org/10.3168/jds.2011-4187.

Domingo, E. 2017. Condiciones de funcionamiento de la máquina para el ordeño de cabras Murciano-Granadina. Bachelor degree final paper. Universitat Politècnica de València, València, Spain.

Fernández, N., A. Martínez, J. V. Martí, M. Rodríguez, and C. Peris. 2015. Milkability and milking efficiency improvement in MurcianoGranadina breed goats. Small Rumin. Res. 126:68-72. https://doi .org/10.106/j.smallrumes.2015.03.001.

Gil, Z. 1988. Milk temperature fluctuations during milking in cows with subclinical mastitis. Livest. Prod. Sci. 20:223-231. https:// doi.org/10.1016/0301-6226(88)90074-7.

Hamann, J., G. A. Mein, and B. Nipp. 1996. Recommended method for measuring changes in thickness of the bovine teat with springloaded calipers. J. Dairy Res. 63:309-313.

Hamzaoui, S., A. A. Salama, E. Albanell, X. Such, and G. Caja. 2013. Physiological responses and lactational performances of latelactation dairy goats under heat stress conditions. J. Dairy Sci. 96:6355-6365. https://doi.org/10.3168/jds.2013-6665.

Isaksson, A., and O. Lind. 1992. Teat reactions in cows associated with machine milking. Zentralbl Veterinarmed A 39:282-288.

ISO. (International Organization for Standardization). 2006. ISO 13366-2/IDF 148-2: Milk-Enumeration of Somatic Cells, Part 2: Guidance on the Operation of Fluoro-opto-electronic Counter. International Organization for Standardization, Geneva, Switzerland.

Labussière, J. 1984. Etude des aptitudes laitières et de la facilite de traite de quelques races de brebis du "Basin Mediterraneen". Pages 730-790 in Proc. 3rd International Symposium on Milking of the Small Ruminants, Valladolid, Spain. Comité Español III Symposium Internacional de Ordeño Mecánico de Pequeños Rumiantes, Valladolid, Spain.

Le Du, J., and B. Benmederbel. 1984. Aptitude des chèvres de race Saanen à la traite mécanique. Relations avec les caractéristiques physiques du trayon. Ann. Zootech. 33:375-384.
Marnet, P. G., P. Billon, G. Da Ponte, J. Martin, and E. Manfredi. 2001. Aptitude à la traite mécanique chez la chevre: Variabilité génétique et bases physiologiques du débit du lait. Pages 321-327 in Rencontres Recherche Ruminants, Paris, France. ITOVIC, Paris, France.

Mein, G. A., R. A. Sherlock, and R. W. Claycomb. 2004. Making sense of in-line sensing for milk conductivity. Pages 252-253 in Automatic Milking. A. Meijering, H. Hogeveen, and C. J. A. M. de Konig, ed. Wageningen Academic Publishers, Wageningen, the Netherlands.

Neijenhuis, F., G. A. Mein, J. S. Britt, D. J. Reinemann, J. E. Hillerton, R. Farnsworth, J. R. Baines, T. Hemling, I. Ohnstad, N. Cook, W. F. Morgan, and L. Timms. 2001. Evaluation of bovine teat condition in commercial dairy herds: 4 . Relationship between teat end callosity or hyperkeratosis and mastitis. Pages $362-366$ in Proc. AABP-NMC II International Symposium on Mastitis and Milk Quality, St. Louis, MO. National Mastitis Council Proceedings Library.

Norberg, E., and I. R. Korsgaard. 2004. Electrical conductivity of milk as an indicator trait for mastitis. Pages 254-255 in Automatic Milking. A. Meijering, H. Hogeveen, and C. J. A. M. de Konig, ed. Wageningen Academic Publishers, Wageningen, the Netherlands.

Peris, S., G. Caja, X. Such, R. Casals, A. Ferret, and C. Torre. 1997. Influence of kid rearing systems on milk composition and yield of Murciano-Granadina dairy goats. J. Dairy Sci. 80:3249-3255.

Requena, R., S. Balasch, C. Peris, M. Rodríguez, and N. Fernández. 2010. Dose response of lactating dairy ewes during suckling and milking to bovine somatotropin. J. Anim. Sci. 88:3136-3144.

Ruiz, I. 2008. Valoración morfológica en ganado caprino lechero. Cabra Murciano-Granadina, ed. Comunidad Autónoma de la Región de Murcia, Murcia, Spain.

SAS Institute. 2011. SAS User's Guide: Statistics. Version 9.2. SAS Institute Inc., Cary, NC.

Sauvant, D., S. Giger-Reverdin, and F. Meschy. 2007. Alimentation des caprins. Pages 137-148 in Alimentation des Bovines, Ovins et Caprins. Ed. Quae, Versailles, France.

Such, X. 1990. Factores condicionantes de la aptitud al ordeño mecánico de ovejas de raza Manchega: Influencia de la simplificación de rutina y las características de la máquina de ordeño. MS Thesis. Universitat Autonoma de Barcelona, Barcelona, Spain.

Zecconi, A., J. Hamann, V. Bronzo, and G. Ruffo. 1992. Machine induced teat tissue reactions and infection risk in a dairy herd from contagious mastitis. J. Dairy Res. 59:265-271.

\section{ORCIDS}

N. Fernández @ https://orcid.org/0000-0001-7150-2903

C. Peris (ㅇ https://orcid.org/0000-0003-3529-1269 